\title{
The Relationship Between Prospective Teachers' Learning Responsibility and Their Readiness for Teaching Profession
}

\author{
Umut Birkan Ozkan ${ }^{1, *} \&$ Kemal Oguz $\operatorname{Er}^{2}$ \\ ${ }^{1}$ Department of Educational Sciences, National Defence University, Balikesir, Turkey \\ ${ }^{2}$ Department of Educational Sciences, Balikesir University, Balikesir, Turkey \\ *Correspondence: Department of Educational Sciences, National Defence University, Altieylul, Balikesir, Turkey. \\ Tel: 90-266-221-2351. E-mail: umutbirkanozkan@gmail.com
}

Received: April 2, $2020 \quad$ Accepted: May 26, $2020 \quad$ Online Published: June 20, 2020

doi:10.5430/wje.v10n3p199 URL: https://doi.org/10.5430/wje.v10n3p199

\begin{abstract}
This study aims to investigate the relationship between prospective teachers' level of performing behaviors related to learning responsibility and their level of readiness for teaching profession. The pre-service teachers $(n=408)$, who are in their second year at the Faculty of Education, filled in the Learning Responsibility Scale and the Readiness Scale for Teaching Profession. The Learning Responsibility Scale consists of 28 Likert-type questions and includes the subscales entitled preparation for learning, active engagement in learning, monitoring learning outcomes and enriching learning. Pearson's correlations and multiple linear regression analyzes were used to analyze the data. The results of the analysis revealed that there was a negative by moderately significant relationship between the prospective teachers' learning responsibilities and their readiness for teaching profession. In addition, it was found out that the variables of learning responsibility explained $12 \%$ of the variation in prospective teachers' scores of readiness for the profession. Active engagement in learning contributed negatively to explain the prospective teachers' readiness for teaching profession.
\end{abstract}

Keywords: learning responsibility, learning responsibility behaviors, readiness, teaching profession, prospective teachers

\section{Introduction}

Today, when the changes in teachers' roles are reviewed and reconsidered, the emphasis on teachers' being good learners is becoming more and more evident. Although it is easier to provide the desired qualities to a teacher candidate who is continuously learning in his/her lifetime, students' own learning also depends on their willingness to take personal responsibility. In order to become a lifelong learner, prospective teachers should take responsibility for their learning to some extend (Devlin, 2002). In addition, teacher training institutions try to achieve their goal to train life-long learning teachers who feel ready for teaching profession (Rosas \& West, 2011; Swabey, Castleton, \& Penney, 2010). The fact that a teacher candidate feels ready for the profession is related to whether the education they receive at the education faculties can gird them for the difficulties of teaching profession (Black, 2003). In this phase, prospective teachers need to know how students learn, the subjects they are in charge of and how to teach them, the implementation of the educational program and many other issues that can make them ready for teaching profession as well as how they personally learn (Schulz \& Mandzuk, 2005). It can be surely said that in order for the prospective teachers to know these issues well, they should learn more about these issues and feel "responsible" or "to be held responsible" to learn them (Bacon, 1993: 199). Therefore, it can be stated that there is a relationship between prospective teachers' taking responsibility for learning and getting ready to do the teaching profession.

Learning responsibility is thought to play an important role in being ready for the profession. In the literature review, it is seen that the concept of responsibility is directly linked to the readiness for the profession (Coorey \& Firth, 2013; Dickinson, 1995; Gurney, 2007; National Association of State Directors of Career and Technical Education Consortium [NASDCTEc], 2012; National Work Readiness Council [NWRC], 2006; O’Connor \& Jackson, 2008). O'Connor and Jackson (2008), who have come up with a model that shows responsibility as a mediate in the relationship between learning styles and functional behavior, denote that one of the important determinants of job 
performance is responsibility. Gurney (2007) states that learning reponsibility is one of the factors that must be interacted with each other in order to be an effective teacher. In their study on integrated contextual learning (ICT), which is one of the methodologies used to increase vocational readiness, Coorey and Firth (2013) emphasize that one of the main components of vocational readiness is the students' responsibility to learn and that students should take responsibility for their own learning. Dickinson's (1995) which shows that the more the students have learning responsibilities, the more they believe in their own abilities put forths the idea that this may also be valid for prospective teachers' readiness for the profession. According to NASDCTEc (2012), responsibility skill is one of the vocational preparation skills. One of the skills that NWRC defined as critical for new employees to succeed in today's workplace and global economy and that it evaluates while giving National Work Readiness Credential is the responsibility of learning (NWRC, 2006). In this context, the role of prospective teachers' learning responsibilities in acquiring skills for teaching profession or their having competencies for teaching profession can be understood by revealing the relationship between prospective teachers' learning responsibility levels and their readiness for teaching profession. Determining the relationship between prospective teachers' learning responsibility levels and their readiness for teaching profession may lead to structural changes in pre-service teacher training programs. In addition, the fact that the relationship between prospective teachers' learning responsibility levels and their readiness for teaching profession has never been investigated so far increases the significance of the study. Accordingly, this study aims to determine the relationship between the prospective teachers' levels of fulfilling the requirements within the scope of learning responsibility behaviors in the context of school-learning and their level of readiness for teaching profession. To achieve this goal, the following questions are tried to be answered:

1. Is there a significant relationship between prospective teachers' learning responsibilities and their levels of readiness for teaching profession?

2. Do the prospective teachers' behaviors within the scope of learning responsibility predict their levels of readiness for teaching profession?

\subsection{Literature Review}

\subsubsection{Responsibility for Learning}

According to Dickinson (1993), students' taking responsibility for their own learning is mainly about making decisions about their own learning. People who believe that success or failure are due to their own efforts tend to take responsibility for their own learning (Dickinson, 1995). According to Barr and Tagg (1995), when a person takes responsibility for his/her own learning; s/he sets goals and then takes action to achieve those goals and constantly changes his/her behavior to achieve the goals better.

In the literature, there are various studies conducted to measure the responsibility of learning (Eristi, 2017; Magno, 2010; Magno, 2011; O’Connor \& Jackson, 2008; Yakar \& Saracaloğlu, 2017; Zimmerman \& Kitsantas, 2005). O'Connor and Jackson (2008) measured "responsibility" as one of the sub-dimensions of the scale which they developed as a part of their study to identify individual differences in learning styles. In the study by Yakar and Saracaloğlu (2017), a scale was developed in order to determine the secondary school students' levels of responsibility for learning. Within the scope of their study in which they investigated the role of high school students' homework practices on the use of specific learning processes, students' perceptions of academic responsibility and their self-efficacy beliefs regarding academic achievement, Zimmerman and Kitsantas (2005) developed a learning scale including 18 items that would determine the perceived responsibility. In his study with Filipino college students, Magno (2010) found that responsibility for learning was a sub-dimension of the academic self-regulation scale. The results of Magno's (2011) study which intended to create a learning responsibility scale for university students showed the psychometric properties of the learning responsibility scale in terms of factor structure, convergent validity, internal consistencies, measurement precision and threshold levels. In the study, in which Eristi (2017) aimed to develop a scale that would enable determining the state of fulfillment of behaviors in learning responsibilities, it was concluded that the developed scale was a tool with a high level of validity and reliability that could be used to determine the extent of the learning responsibility behaviors fulfilled by the university students.

\subsubsection{Readiness for Teaching Profession}

According to Straková (2015), readiness is the feeling of being ready for work, considering all aspects and elements that contribute to this feeling during pre-service training. Housego (1990) suggests that prospective teachers' feelings of readiness may affect their ability to perform their teaching tasks. Li (1999) states that their readiness for teaching is related to their performance in the classroom, and that those with high readiness levels will have the feeling that they will perform better in the classroom. Darling-Hammond, Chung and Frelow (2002) revealed that teachers' 
regarding themselves ready for the profession is highly linked to their feeling of being effective, being responsible for the students' learning and their future career in their professions. This result showed the importance of evaluating the prospective teachers' readiness for teaching profession.

There are various studies on the prospective teachers' readiness for the profession (Housego, 1990; Mehmetlioglu \& Haser, 2013; Straková, 2015; Swabey, Castleton, \& Penney, 2010; Yildirim \& Koklukaya, 2017). Swabey, Castleton and Penney (2010) carried out interviews with randomly selected prospective teachers and focused on the prospective teachers' perceptions of their pre-service preparations to get ready to perform the teaching task. It was found that prospective teachers felt that they got prepared well enough in terms of many elements in the teaching profession standards.

In the study where Straková (2015) asked prospective teachers to score their feelings of being ready for the profession ranging from 0 to 100 , it was concluded that prospective teachers perceived themselves as well-prepared for teaching profession and gave themselves an average point of 79. Housego (1990) designed 7-point likert-type Student Teachers' Feelings of Preparedness for Teaching (PREP) scale including 50 items to investigate how teacher candidates felt ready for teaching. It was considered that the higher the score a prospective teacher got, the higher their readiness for teaching profession was. On the other hand, Mehmetlioglu and Haser (2013) analyzed the data which they had collected from 728 prospective teachers of elementary mathematics by using the readiness scale developed by them and at the end of the study, they concluded that the candidates did not find themselves highly prepared for teaching profession. As a result of their work to develop a valid and reliable readiness scale to determine the readiness levels of teacher candidates for teaching profession, Yildirim and Koklukaya (2017) found that prospective teachers' readiness levels vary according to the items in the scale and that their readiness levels were low.

\section{Method}

In this study, which was a relational survey model of quantitative research, it was aimed to determine the relationship between prospective teachers' learning responsibility levels and their readiness levels for teaching profession. Moreover, it tended to examine the predictive role of the sub-dimensions of learning responsibility on prospective teachers' readiness for profession.

\subsection{Participants}

The research was carried out with 408 prospective teachers studying at Necatibey Faculty of Education, Balikesir University. Demographic data about the participants are shown in Table 1.

Table 1. Demographic Data about the Participants

\begin{tabular}{llcc}
\hline Category & & \multicolumn{2}{c}{ Total } \\
& & Definition & N \\
\cline { 2 - 4 } Gender & Female & 283 & 69.4 \\
& Male & 125 & 30.6 \\
\multirow{5}{*}{ Department } & Total & 408 & 100 \\
& Basic Sciences & 111 & 27.2 \\
& Social Sciences & 297 & 72.8 \\
& Total & 408 & 100 \\
Type of Residence & With family & 124 & 30.4 \\
& Single person & 111 & 27.2 \\
& Single or double room (dorm) & 100 & 24.5 \\
& More than two people (dorm) & 73 & 17.9 \\
& Total & 408 & 100 \\
\hline
\end{tabular}

\subsection{Instruments}

The teacher candidates were asked to fill in two instruments and return them to the researcher. One of the instruments is a scale formed by Eristi (2017) and it is about the learning responsibilities of prospective teachers. The learning responsibility scale consists of 28 items with different sub-categories such as preparation for learning (7 items), active engagement in learning (9 items), monitoring learning outcomes ( 8 items) and enriching learning (4 items). The other instrument is a 30 -item scale that determines the prospective teachers' readiness for teaching profession, formed by Yildirim \& Koklukaya (2017). The reliability of the scales and the sub-dimensions of the 
scales were determined with Cronbach’s Alpha Internal Consistency Coefficients (Table 2).

Table 2. Cronbach $\alpha$ Coefficients of the Scales Used

\begin{tabular}{|c|c|c|}
\hline Scale & Factor & $\alpha$ Value (For Sub-dimensions and Whole Scale) \\
\hline & Preparation for Learning & .738 \\
\hline Scale of Learning & Active Engagement in Learning & .831 \\
\hline \multirow[t]{2}{*}{ Responsibility } & Monitoring Learning Outcomes & .848 \\
\hline & Enriching Learning & .798 \\
\hline Scale of Profession & & .912 \\
\hline
\end{tabular}

As seen in Table 2, the sub-elements of thee learning responsibility scale have sufficient internal consistency with values ranging from .74 to .85 (Hajjar, 2018; Streiner, 2003). Reliability of learning responsibility and readiness for teaching profession scales (.92 and .91) have also been found to be satisfactory (Hajjar, 2018; Streiner, 2003).

\subsection{Data Analysis}

To determine whether the data shows normal distribution, kurtosis and skewness values have been examined. Table 3 shows the mean, mode, median, skewness and kurtosis values of the variables.

Table 3. Normality Tests

\begin{tabular}{lccccc}
\hline & Mean & Mode & Median & Skewness & Kurtosis \\
\hline Preparation for learning & 3.68 & 3.86 & 3.71 & -.604 & .447 \\
Active engagement in learning & 3.75 & 4.00 & 3.77 & -.142 & -.096 \\
Monitoring learning outcomes & 3.68 & 4.00 & 3.75 & -.629 & .476 \\
Enriching learning & 3.45 & 4.00 & 3.50 & -.597 & .476 \\
Readiness for teaching profession & 59.23 & 62.00 & 60.00 & -.055 & 139 \\
\hline
\end{tabular}

As understood from the values in Table 3, the mean, mode and median values are very close to each other, and therefore the data is distributed symmetrically around the central tendency measures. In cases where these values are not equal, the normality of the series can be found out by interpreting the skewness and kurtosis values. Various opinions regarding kurtosis and skewness values suggest that these values can be accepted in the range of -1 to +1 (Morgan, Leech, Gloeckner \& Barrett, 2004) or -2 and +2 (George \& Mallery, 2010) to provide normality assumptions. In this study, it can be said that the scores show normal distribution as the skewness and kurtosis values are between -1 and +1 .

Pearson's correlations were used to find out whether there is a relationship between learning responsibility and readiness for teaching profession. Multiple linear regression analysis was carried out to examine the predictive role of the sub-dimensions of learning responsibility on the prospective teachers' readiness for the profession. In this study, the multiple linear regression mathematical model created to examine the determination of the sub-dimensions of the learning responsibility on the prospective teachers' readiness for the profession can be written as follows:

$$
y=\beta 0+\beta 1 \times 1+\beta 2 \times 2+\beta 3 \times 3+\beta 4 \times 4+\varepsilon
$$

y : Prospective teachers' professional readiness scores

$\beta \mathrm{n} \quad$ : Partial regression coefficient

$\mathrm{x} 1 \quad$ : Preparation for learning

$\mathrm{x} 2$ : Active engagement in learning

x3 : Monitoring learning outcomes

$\mathrm{x} 4$ : Enriching learning

$\varepsilon \quad:$ Error term

Correlation matrix performed to check whether there are multi-collinearity problems among the predictive variables is given in Table 4. 
Table 4. Correlation Matrix between Predictive Variables

\begin{tabular}{lcccc}
\hline \multicolumn{1}{c}{ Variables } & $\begin{array}{c}\text { Preparation for } \\
\text { learning }\end{array}$ & $\begin{array}{c}\text { Active engagement in } \\
\text { learning }\end{array}$ & $\begin{array}{c}\text { Monitoring learning } \\
\text { outcomes }\end{array}$ & $\begin{array}{c}\text { Enriching } \\
\text { learning }\end{array}$ \\
\hline Preparation for learning & 1 & & & \\
Active engagement in learning & .748 & 1 & 1 & \\
Monitoring learning outcomes & .676 & .686 & .738 & 1 \\
Enriching learning & .748 & .739 & & 1 \\
\hline
\end{tabular}

According to the values given in Table 4, it can be argued that there is no multi-collinearity problem among the predictor variables of this study since the mutual correlations between the predictive variables aren't above the limit of 0.80 (Buyukozturk, 2013), as recommended in the literature. The tolerance, variance inflation factor (VIF) and condition indices $(\mathrm{CI})$ values of the predictive variables included in the analysis are given in Table 5.

Table 5. Tolerance, VIF and CI Values of Predictive Variables

\begin{tabular}{lccc}
\hline & Tolerance & VIF & CI \\
\hline Preparation for learning & .346 & 2.888 & 16.244 \\
Active engagement in learning & .350 & 2.856 & 24.139 \\
Monitoring learning outcomes & .401 & 2.493 & 26.697 \\
Enriching learning & .314 & 3.187 & 28.220 \\
\hline
\end{tabular}

In the analysis, the tolerance value of the independent variables is lower than .20 , the VIF value is higher than 10 and the CI value is higher than 30, which means that there is multi-collinearity between the variables (Buyukozturk, 2013). When the values in Table 5 are analyzed, it is seen that the tolerance, VIF and CI values of the predictive variables meet these conditions. IBM SPSS Statistic 22 package program was used in the analysis.

\section{Results}

\subsection{Addressing the First Research Question}

The first research question aims to determine whether there is a significant relationship between prospective teachers' learning responsibilities and their readiness for teaching profession. The results of Pearson's correlations are presented in Table 6.

Table 6. Pearson Correlation Coefficients Between Pre-Service Teachers' Readiness for Teaching Profession and Learning Responsibility

Readiness for Teaching Profession

Learning Responsibility (Scale)

Learning Responsibility Subscale 1: Preparation for learning

Learning Responsibility Subscale 2: Active engagement in learning

Learning Responsibility Subscale 3: Monitoring learning outcomes

Learning Responsibility Subscale 4: Enriching learning

**Correlation is significant at the 0.01 level (2-tailed).
$-.348^{* *}$

$-.309^{* *}$

$-.335^{* *}$

$-.293^{* *}$

$-.288^{* *}$

The correlations presented in Table 6 show that there is a moderate, negative and meaningful relationship between prospective teachers' learning responsibilities and their readiness for teaching profession. The sign of the Pearson Correlation Coefficient gives us with the direction of the relationship between the two variables. The Pearson Correlation coefficient of Learning Responsibility is $\mathrm{r}=.348$ and is negative, so there is a negative correlation between the "readiness for teaching profession" and "learning responsibility" scores. In addition, all subscales of learning responsibility and readiness for teaching profession, with Pearson Correlation Coefficients ranging from .288 to .335 , have negative correlations with each other.

\subsection{Addressing the Second Research Question}

The second research question aimed to determine the predictability of prospective teachers' behaviors within the scope of learning responsibility on their readiness for teaching profession. Multiple regression analysis was carried 
out to answer this research question. To see which behaviors within the scope of learning responsibility can predict prospective teachers' readiness for teaching profession, associated independent variables (behaviors within the context of learning responsibility) and their readiness for teaching profession were regressed. Table 7 presents the model summary of the regression analysis for the prospective teachers' readiness for teaching profession, and the results of the regression coefficients are given in Table 8.

Table 7. Model Summary for Teacher Candidates' Readiness for Teaching Profession

\begin{tabular}{lllll}
\hline Model & $\mathrm{R}$ & $\mathrm{R}^{2}$ & Adjusted $\mathrm{R}^{2}$ & Std. Error of the Estimate \\
\hline 1 & $.352^{\mathrm{a}}$ & .124 & .115 & 15.74829 \\
\hline
\end{tabular}

a. Predictors: (Constant). preparation for learning. active engagement in learning. monitoring learning outcomes. enriching learning.

Table 8. Regression Coefficients for the Predictors of Pre-Service Teachers' Preparedness for Teaching Profession

\begin{tabular}{lccccccc}
\hline & \multicolumn{2}{c}{$\begin{array}{c}\text { Unstandardized } \\
\text { Coefficients }\end{array}$} & \multicolumn{2}{c}{$\begin{array}{c}\text { Standardized } \\
\text { Coefficients }\end{array}$} & & & \\
\cline { 2 - 5 } \multicolumn{1}{c}{ Model } & $\mathrm{B}$ & Std. Error & Beta & $\mathrm{t}$ & \multicolumn{2}{c}{ Sig. } & Part Correlation \\
\hline (Constant) & 107.354 & 5.630 & & 19.069 & .000 & -.058 \\
Preparation for learning & -2.637 & 2.116 & -.099 & -1.246 & .213 & -.118 \\
Active engagement in learning & -5.608 & 2.212 & -.200 & -2.535 & .012 & -.055 \\
Monitoring learning outcomes & -2.628 & 2.224 & -.087 & -1.181 & .238 & -.002 \\
Enriching learning & -.066 & 2.062 & -.003 & -.032 & .974 & - \\
\hline
\end{tabular}

The multiple regression analysis results presented in Table 7 reveal that the variables of learning responsibility explain $12 \%$ of the variation in prospective teachers' scores of readiness for the profession $\left(\mathrm{R}^{2}=.12\right)$. According to Table 8, independent variables (learning responsibility behaviors) other than active engagement in learning aren't statistically significant. Also, active engagement in learning with a value of -.20 Beta contributes negatively to explain the prospective teachers' readiness for teaching profession.

\section{Discussion}

This study has examined the extent to which prospective teachers' behaviors within the scope of learning responsibility are related to their readiness for teaching profession. According to the findings of the study, prospective teachers who have more responsibility to learn feel less ready for teaching profession. Apart from that, active engagement in learning is the most important predictor of prospective teachers' readiness for teaching profession.

First, the results in the correlation table (Table 6) show that there is a significant negative relationship between prospective teachers' readiness for teaching profession and their behaviors within the scope of learning responsibility. In other words, prospective teachers feel less prepared for teaching profession as they take more responsibility for their own learning. This may be because prospective teachers feel that they need to make more efforts to be more prepared for teaching. The negative correlation between displaying behaviors that enrich learning, which is one of the responsibilities of learning, and being ready for teaching, supports this idea. This result is consistent with the previous studies in the literature (Stites et al., 2018; Ronfeldt et al., 2018). In the study of Stites et al. (2018), prospective teachers think they need additional development to be fully prepared for teaching. In addition, the report by Ronfeldt et. al. (2018), which shows that prospective teachers' taking more lessons during their education and studying more for the lessons make them feel ready for teaching profession coincides with the finding that prospective teachers who need to prepare more for learning and to participate effectively in learning feel less ready for teaching.

In regard to the predictive power (second research question) of prospective teachers' behaviors within the scope of learning responsibility on their readiness for teaching profession, the results of the regression analysis has revealed that active engagement in learning explains a small amount of variance in readiness for teaching profession. However, this small contribution to the readiness of prospective teachers should be taken into consideration. Effective participation in learning (students' actions, efforts, and behaviors within the scope of learning responsibility during the course and during the course time) contributed negatively to the prospective teachers' readiness, suggesting that 
over-learning efforts may make prospective teachers feel inadequate in the long term. The main finding of Crosswell and Beutel's (2012) study with newly graduated and prospective teachers is that they are actively seeking more professional learning to improve the practical aspects of their teaching. Therefore, displaying excessive action and effort during the course and acting with a sense of obligation to be ready for the profession may make prospective teachers more vulnerable to the sense of inadequacy for teaching and lead to a feeling of helplessness. This result points to a paradox that poses a problem in professional readiness: while teacher candidates are expected to take more and more learning responsibilities, their readiness for the profession is decreasing. To put it all in simple terms, prospective teachers are expected to be more prepared with greater burden of responsibility.

In this study, the relationship between prospective teachers' behaviors within the scope of learning responsibility and their readiness for teaching profession has been investigated. In addition, the extent to which behaviors within the scope of learning responsibility can contribute to readiness for teaching is examined. The results of the correlation analysis has revealed that there is a negative relationship between prospective teachers' learning responsibilities and their readiness for teaching profession. It has been concluded that learning responsibility may play a role that reduces the momentum of the development of the sense of readiness for the profession among prospective teachers. However, the predictive power of learning responsibility factors should not be used as a comprehensive criterion to explain readiness for teaching profession.

The need for teacher candidates to be ready for a high level of profession is more than ever and education faculties continue to be pioneers in meeting this need. Although the context of readiness for teaching profession is characterized with complex and numerous challenges, it seems that more efforts are needed to ensure that teacher candidates are not burdened with more responsibility than they should handle in their learning processes. Education faculties can develop their long-standing efforts to prepare prospective teachers for the profession by focusing on basic strategies and taking the results expressed in this study into account with strong and innovative preparatory programs.

As a result, it is possible to develop motivation strategies to become ready for teaching by understanding the behaviors under the scope of learning responsibility, which reduces readiness for teaching profession. The findings also suggest that when prospective teachers show excessive behavior of active engagement in learning, they may have a negative impact on their readiness for teaching profession. Therefore, it should be taken into consideration that providing faculty and mentor support to prospective teachers can contribute to the graduates' sense of readiness for teaching (Rots \& Aelterman, 2008). Faculty management, academic staff and counselors can help with the need of prospective teachers' being ready to do their profession by listening to their concerns and empowering them to make their own decisions about their behaviors related to the responsibility of learning.

However, this study has a number of limitations that future research should address. The results of this study should be read carefully due to the limitations in cross-sectional design and the use of a small sample size. Therefore, the results of the study may not show a complete picture of all prospective teachers' readiness for the profession. Further research is needed in the future to confirm the results of the study and to investigate the role of learning responsibility as a risk factor for professional readiness. To discover the role of different types of preparation in feeling ready for teaching and to reveal the causal relationship between pre-service teachers' learning responsibilities and professional readiness, longitudinal studies can be carried out. In addition, some other educational variables, such as pre-service teachers' learning strategies, can be explored in terms of learning responsibility and readiness for teaching profession.

As the results of the multiple regression analysis show, learning responsibility explains only $12 \%$ of prospective teachers' readiness for the profession. It is unrealistic to assume that prospective teachers have experiences without the influence of any other factors throughout their education. It can be said that prospective teachers make sense of these experiences through their personal philosophy and understanding. Therefore, in order to deepen and elaborate the relationships between the variables in the current study model; qualitative research can be carried out to reveal the objective perceptions and experiences of prospective teachers about learning responsibility and readiness for teaching profession.

\section{References}

Bacon, C. S. (1993). Student responsibility for learning. Adolescence, 28(109), 199-212.

Barr, R. B., \& Tagg, J. (1995). From teaching to learning-A new paradigm for undergraduate education. Change: The Magazine of Higher Learning, 27(6), 12-26. https://doi.org/10.1080/00091383.1995.10544672 
Black, M. W. (2003). A study of first-year teachers and their principals: Perceptions of readiness among participants from traditional and non-traditional teacher preparation programs (Unpublished doctoral dissertation). Fayetteville State University.

Buyukozturk, S. (2013). Sosyal bilimler için veri analizi el kitabı: Istatistik, araştırma deseni SPSS uygulamaları ve yorum [Data analysis handbook for social sciences, statistics, research design, SPSS applications and comments]. Ankara: PegemA.

Coorey, R., \& Firth, A. (2013). Integrated contextual learning and food science students' perception of work readiness. Journal of Food Science Education, 12(2), 20-27. https://doi.org/10.1111/1541-4329.12003

Crosswell, L., \& Beutel, D. (2012). Investigating pre-service teachers' perceptions of their preparedness to teach. International Journal of Learning, 18(4), 203-211.

Darling-Hammond, L., Chung, R., \& Frelow, F. (2002). Variation in teacher preparation: How well do different pathways prepare teachers to teach?. Journal of Teacher Education, 53(4), 286-302. https://doi.org/10.1177/0022487102053004002

Devlin, M. (2002). Taking responsibility for learning isn't everything: A case for developing tertiary students' conceptions of learning. Teaching in Higher Education, $7(2), \quad 125-138$. https://doi.org/10.1080/13562510220124231

Dickinson, L. (1993). Talking shop: Aspects of autonomous learning. ELT Journa1, 47(4), 330-336. https://doi.org/10.1093/elt/47.4.330

Dickinson, L. (1995). Autonomy and motivation a literature review. System, 23(2), $165-174$. https://doi.org/10.1016/0346-251X(95)00005-5

Eristi, B. (2017). Öğrenme sorumluluğu ölçeğinin geliştirilmesi. Necatibey Eğitim Fakültesi Elektronik Fen ve Matematik Ĕ̈itimi Dergisi, 11(1), 481-503.

George, D., \& Mallery, M. (2010). SPSS for windows step by step: A simple guide and reference, 17.0 update (10th ed.). Boston: Pearson.

Gurney, P. (2007). Five factors for effective teaching. New Zealand Journal of Teachers' Work, 4(2), 89-98.

Hajjar, S. T. E. (2018). Statistical analysis: Internal-consistency reliability and construct validity. International Journal of Quantitative and Qualitative Research Methods, 6(1), 46-57.

Housego, B. E. (1990). Student teachers' feelings of preparedness to teach. Canadian Journal of Education/Revue Canadienne de l'Education, 15(1), 37-56. https://doi.org/10.2307/1495416

Li, X. (1999). Preparedness to teach: A comparison between consecutive and concurrent education students. Alberta journal of Educational Research, 45(2), 184-197.

Magno, C. (2010). Assessing academic self-regulated learning among Filipino college students: The factor structure and item fit. The International Journal of Educational and Psychological Assessment, 5, 61-76.

Magno, C. (2011). Establishing a scale that measures responsibility for learning. The International Journal of Educational and Psychological Assessment, 8(2), 31-42.

Mehmetlioglu, D., \& Haser, C. (2013). İlköğretim matematik öğretmen adaylarının mesleğe hazır bulunuşlukları, [Preservice elementary mathematics teachers' preparedness for the teaching profession]. Pamukkale University Journal of Education, 34, 91-102.

Morgan, G. A., Leech, N. L., Gloeckner, G. W., \& Barrett, K. C. (2004). SPSS for introductory statistics: Use and interpretation (2nd ed.). Mahwah, NJ: Lawrence Erlbaum Associates.

National Association of State Directors of Career and Technical Education Consortium (NASDCTEc). (2012). Common career technical core. Silver Spring, MD: National Career Technical Education Foundation.

National Work Readiness Council (NWRC). (2006). Getting ready for the work readiness credential: a guide for trainers and instructors of jobseekers. Tallahassee, Florida: NWRC.

O’Connor, P. J., \& Jackson, C. J. (2008). The factor structure and validity of the Learning Styles Profiler (LSP). European Journal of Psychological Assessment, 24(2), 117-123. https://doi.org/10.1027/1015-5759.24.2.117

Ronfeldt, M., Matsko, K. K., Greene Nolan, H., \& Reininger, M. (2018). Who knows if our teachers are prepared? Three different perspectives on graduates' instructional readiness and the features of preservice preparation 
that predict them (CEPA Working Paper No.18-01). Retrieved from http://cepa.stanford.edu/wp18-01

Rosas, C., \& West, M. (2011). Pre-service teachers' perception and beliefs of readiness to teach mathematics. Current Issues in Education, 14(1), 1-23.

Rots, I., \& Aelterman, A. (2008). Teacher training for secondary education and graduates' entrance into the teaching profession. Educational Studies, 34(5), 399-417. https://doi.org/10.1080/03055690802257176.

Schulz, R., \& Mandzuk, D. (2005). Learning to teach, learning to inquire: A 3-year study of teacher candidates' experiences. Teaching and Teacher Education, 21(3), 315-331. https://doi.org/10.1016/j.tate.2005.01.004

Stites, M. L., Rakes, C. R., Noggle, A. K., \& Shah, S. (2018). Preservice teacher perceptions of preparedness to teach in inclusive settings as an indicator of teacher preparation program effectiveness. Discourse and Communication for Sustainable Education, 9(2), 21-39. https://doi.org/10.2478/dcse-2018-0012

Straková, Z. (2015). The perception of readiness for teaching profession: a case of pre-service trainees. Journal of Language and Cultural Education, 3(1), 32-42. https://doi.org/10.1515/jolace-2015-0003

Streiner, D. L. (2003). Starting at the beginning: an introduction to coefficient alpha and internal consistency. Journal of PersonalityAassessment, 80(1), 99-103. https://doi.org/10.1207/S15327752JPA8001_18

Swabey, K., Castleton, G., \& Penney, D. (2010). Meeting the standards? Exploring preparedness for teaching. Australian Journal of Teacher Education, 35(8), 29-46.

Yakar, A., \& Saracaloglu, A. S. (2017). Öğrenmeye yönelik sorumluluk ölçeği [Scale of responsibility towards learning]. Mehmet Akif Ersoy University Journal of Education Faculty, 42, 27-49. https://doi.org/10.21764/efd.41545

Yildirim, E. G., \& Koklukaya, A. N. (2017). Öğretmenlik mesleğine yönelik hazırbulunuşluk ölçeğinin geliştirilmesi ve fen bilgisi öğretmen adaylarının hazırbulunuşluk düzeylerinin belirlenmesi, [Development of readiness scale for teaching profession and determination of science teacher candidates' readiness levels]. International Journal of Social Science, 56, 67-82. http://dx.doi.org/10.9761/JASSS6927

Zimmerman, B. J., \& Kitsantas, A. (2005). Homework practices and academic achievement: The mediating role of self-efficacy and perceived responsibility beliefs. Contemporary Educational Psychology, 30(4), 397-417. https://doi.org/10.1016/j.cedpsych.2005.05.003 